\title{
Primary Cutaneous Nocardiosis Due to Nocardia Farcinica: A Case Report of an Often Overlooked Infection
}

\author{
Siyu Gao* \\ Qiang Liu* \\ Xiaolin Zhou \\ Xiangcheng Dai \\ HuiQing $\mathrm{He}$
}

Yichang Central People's Hospital, The First College of Clinical Medical Science, China Three Gorges University, Yichang, Hubei, People's Republic of China

*These authors contributed equally to this work
This article was published in the following Dove Press journal: Infection and Drug Resistance

\begin{abstract}
Primary cutaneous nocardiosis by Nocardia farcinica is exceedingly rare. Only six cases have been reported from PubMed in the past 15 years. We encounter such a case in a 55-year-old man receiving long-term steroid and cyclophosphamide. Owing to no characteristic symptoms, the disease can be so easily overlooked and causes fatal consequences. Therefore, we herein discuss common features of primary cutaneous nocardiosis by Nocardia farcinica that remind clinicians considering it.
\end{abstract}

Keywords: Nocardia farcinica, cutaneous infection, primary cutaneous nocardiosis, abscess

\section{Introduction}

Nocardiosis is uncommon. Compared with other species, the infection caused by Nocardia farcinica (N.farcinica) represents approximately $10 \%$ of nocardiosis. ${ }^{1}$ And $N$.farcinica has a distinctive antibiotic susceptibility pattern and resistance to antimicrobial agents occurs more frequently. Moreover, primary cutaneous nocardiosis is also rare. Only six case reports of primary cutaneous nocardiosis due to $N$. farcinica have been reported from PubMed in the past 15 years. However, it is likely that infections caused by Nocardia are more frequent than is believed with technological advancements in the identification of isolates. Localized infections caused by it may extend to vital organs. Owing to no characteristic symptoms, this easily overlooked cutaneous infection should be concerned. Recently, we encounter such a case in a 55-year-old patient receiving long-term steroid and cyclophosphamide, which was successfully treated with linezolid, trimethoprimsulfamethoxazole (TMP-SMX) and ultrasound-guided drainage of abscesses.

\section{Case Report}

A 55-year-old man was initially admitted to Pain Care Center in our hospital with no complaint except pain in right thigh of one month's duration. He has nephrotic syndrome with minimal change of glomerulonephritis from 18 months ago and received steroid and cyclophosphamide with an accumulated dosage of $7.2 \mathrm{~g}$. He also has histories of hypertension disease, diabetes, hypothyroidism and lumbar disc herniations with unilateral sciatica pain.

On admission, his vital signs were as follows: temperature $36.3^{\circ} \mathrm{C}$, blood pressure $105 / 62 \mathrm{~mm} \mathrm{Hg}$, pulse rate 62 beats per minute and respiratory rate 21 breaths per minute. A physical examination reported right-thigh tenderness with intact overlying skin and
Correspondence: HuiQing $\mathrm{He}$

Yichang Central People's Hospital, The First College of Clinical Medical Science,

China Three Gorges University, No. 183

Yiling Road, Yichang, 443003, People's

Republic of China

Tel +8613720181669

Email stellarray@I26.com
Infection and Drug Resistance 202I:14 |435-|440

sumit your manuscript

(c) (i) (5) 2021 Gao et al. This work is published and licensed by Dove Medical Press Limited. The full terms of this license are available at https://www.dovepress.com/terms.php cc. you hereby accept the Terms. Non-commercial uses of the work are permitted without any further permission from Dove Medical Prss
permission for commercial use of this work, please see paragraphs 4.2 and 5 of our Terms (https://www.dovepress.com/terms php). 
a positive Fabere test. Systemic symptoms were absent. Laboratory findings collected after admission were as follows: white blood cells, $22.81 \times 10^{\wedge} 9 / \mathrm{L}$; red blood cells, $3.63 \times 10^{\wedge} 12$ / L; hemoglobin, $110 \mathrm{~g} / \mathrm{L}$; platelets, $323 \times 10^{\wedge} 9 / \mathrm{L}$. Blood chemistry documented: lactate dehydrogenase, $466 \mathrm{IU} / \mathrm{L}$; alkaline phosphatase, $137 \mathrm{U} / \mathrm{L}$; C-reactive protein, $176.02 \mathrm{mg} / \mathrm{L}$; erythrocyte sedimentation rate, $89 \mathrm{~mm} / \mathrm{h}$, and procalcitonin, $1.712 \mathrm{ng} / \mathrm{mL}$. Results of urinalysis reported albumin, $80 \mathrm{mg} /$ L. Other laboratory findings were all within the normal range. Magnetic resonance imaging (MRI) of the lower extremities revealed abscesses formation of the right thigh (Figure 1A). Pus samples with ultrasound-guided aspiration were sent for microbial cultures.

Considering that the above findings might be attributed to infection, the patient started three days of treatment on ceftriaxone, but he showed no recovery after applied antibiotics in terms of pain and inflammatory markers. On hospital day four, pus culture reported positive and exhibited Grampositive bacteria. Therefore, antibiotic regimen was changed to empiric piperacillin-tazobactam. However, it still has a poor effect and even swelling of the right thigh experienced, redness appeared and local skin temperature rised. For seeking further reasons, he was transferred to the Department of Infectious Diseases on hospital day six and abscesses were drained under ultrasound guidance. On hospital day seven, pus sample was identified as N.farcinica. The patient's history was investigated again in detail. He recalled a minor thorn injury of his thigh while working outdoors but failed to recall a specific time. Treatment was then switched to TMP-SMX therapy (480 mg orally every 12 hours; the dose was calculated by weight and creatinine clearance).

However, on hospital day ten, the patient experienced elevated body temperature that fluctuated around $37.5^{\circ} \mathrm{C}$. Linezolid (600 mg intravenously every 12 hours) and TMPSMX were used in combination. The patient recovered gradually and an MRI examination showed the previous lesion diminished in size (Figure 1B). He finally reached a complete remission at hospital day 29 and discharged with a prescription of oral TMP-SMX (480 mg every 12 hours), amoxicillin-clavulanate $(200 \mathrm{mg}$, three times a day) for 6 months. Our patient has remained relapse-free at that time of writing.

\section{Discussion}

Nocardiosis is a zoonotic and opportunistic infection that tends to involve in hosts with risk factors like diabetes, renal disease, long-term steroid use, transplantation, pulmonary disease and AIDS, alcoholism and malignancies. ${ }^{2,4}$ The most common infection is pulmonary nocardiosis due to Nocardia asteroides, which estimated to accounts for $80 \%$

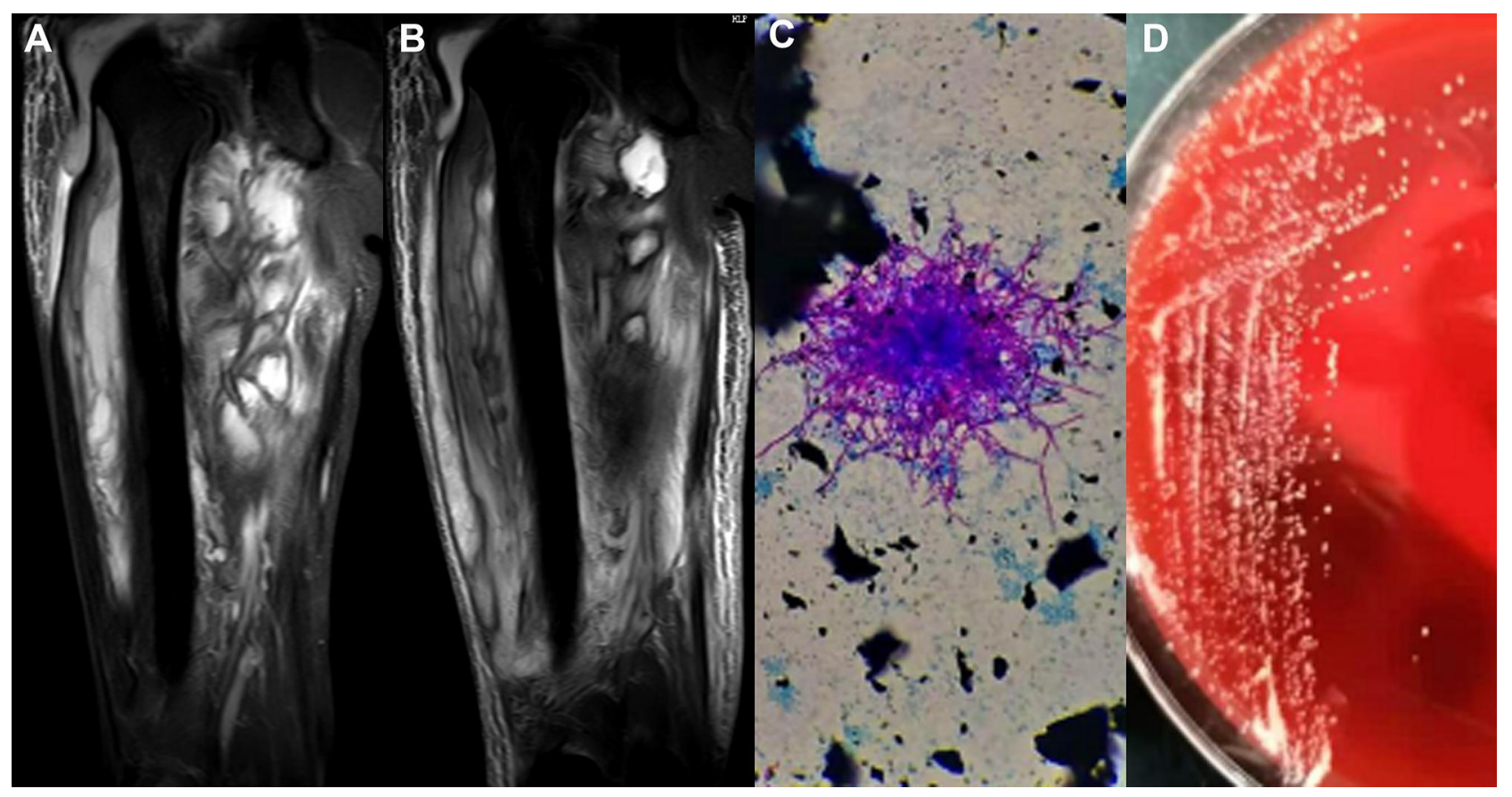

Figure I (A) MRI of the lower extremities showed multiple clumpy abnormal signal lesions, suspected of hematomas or abscesses formation. (B) Abnormal signal lesions decreased than before. (C) Modified Kinyoun acid-fast stain ( $1 \%$ sulfuric acid as a decolorizing agent) revealed red purple branching hyphae in multiple directions ( $10 * 100)$. (D) A routine blood agar plate at 48 hours revealed growth of small and hard white colonies. 
of nocardiosis, followed by the nocardia brain abscess, disseminated nocardiosis and cutaneous nocardiosis due to Nocardia brasiliensis. ${ }^{1,4}$ Cutaneous infection caused by $N$. farcinica is rare, and mostly secondary to late systemic dissemination. Primary cutaneous nocardiosis due to N.farcinica is extremely rare, which predominantly results from skin damage or traumatic injury, and preferentially develops in immunocompetent hosts unlike other forms of nocardiosis infecting immunocompromised hosts. ${ }^{3,5}$ In addition, $N$.farcinica is reportedly associated with high risk of dissemination and death, and infections by N.farcinica are increasing because of technological advancements in the identification of isolates. ${ }^{4}$ Therefore, primary cutaneous infection by $N$. farcinica is particularly noteworthy because it can be easily overlooked and later develops into a fatal disease.

In our case, this patient usually works outdoors as an electrician, and he also had a minor thorn injury of thigh. He felt pain in injured thigh soon after the injury. In subsequent examinations, only thigh lesions were detected and a systemic invasive infection was ruled out. Moreover, he had underlying diseases of diabetes and nephrotic syndrome. Therefore, he was diagnosed with primary cutaneous nocardiosis. Characteristics of our patient are summarized in Table 2.

In the past 15 years, a total of six case reports of primary cutaneous nocardiosis due to N.farcinica were collected from PubMed (Table 1). ${ }^{4,6-10}$ Six patients had

Table I Clinical Characteristics of 6 Patients with Primary Cutaneous Nocardiosis Due to N.farcinica Reported in Case Reports from 2006 to 2020

\begin{tabular}{|c|c|c|c|c|c|c|c|c|}
\hline Year & $\begin{array}{l}\text { Agel } \\
\text { Gender }\end{array}$ & Occupation & $\begin{array}{l}\text { Clinical } \\
\text { Manifestations }\end{array}$ & $\begin{array}{l}\text { Underlying } \\
\text { Condition }\end{array}$ & $\begin{array}{l}\text { Steroids and/or } \\
\text { Other } \\
\text { Immunosuppressants }\end{array}$ & Therapy & $\begin{array}{l}\text { Antimicrobial } \\
\text { Susceptibility } \\
\text { Testing }\end{array}$ & Outcome \\
\hline $2006^{6}$ & $65 / F$ & NA & $\begin{array}{l}\text { Chills, nausea, } \\
\text { elevated body } \\
\text { temperature } \\
\left(37.5^{\circ} \mathrm{C}\right) \text {; pain, } \\
\text { swelling and } \\
\text { erythema of } \\
\text { right thigh }\end{array}$ & $\begin{array}{l}\text { Hodgkin's } \\
\text { lymphoma }\end{array}$ & $\begin{array}{l}\text { Methotrexate, } \\
\text { vinblastine, bleomycin }\end{array}$ & $\begin{array}{l}\text { TMP/ } \\
\text { SXM (3 } \\
\text { mo) }\end{array}$ & $\begin{array}{l}\text { Susceptible to } \\
\text { AMK, AMC, } \\
\text { CRO, IPM, TMP/ } \\
\text { SXM and MI; } \\
\text { resistant to CIP, } \\
\text { TOB and CLR }\end{array}$ & Cured \\
\hline $2008^{4}$ & $72 / M$ & Mining & $\begin{array}{l}\text { Painful nodules } \\
\text { of the forearm, } \\
\text { wrist, and } \\
\text { buttocks }\end{array}$ & $\begin{array}{l}\text { Multiple } \\
\text { myeloma }\end{array}$ & $\begin{array}{l}\text { Cyclophosphamide, } \\
\text { dexamethasone, } \\
\text { lenalidomide }\end{array}$ & $\begin{array}{l}\text { TMP/ } \\
\text { SXM (6 } \\
\text { mo) }\end{array}$ & $\begin{array}{l}\text { Susceptible to } \\
\text { AMK, TMPI } \\
\text { SXM, LZD, and } \\
\text { CIP; resistant to } \\
\text { CRO, IPM and } \\
\text { CLR }\end{array}$ & Cured \\
\hline $2011^{7}$ & $37 / M$ & Farmer & $\begin{array}{l}\text { Painful nodules } \\
\text { and ulcers of left } \\
\text { legs }\end{array}$ & HBV carrier & None & $\begin{array}{l}\text { TMP/ } \\
\text { SXM }\end{array}$ & None & NA \\
\hline $2012^{8}$ & $3 \mathrm{I} / \mathrm{F}$ & NA & $\begin{array}{l}\text { A small ulcer of } \\
\text { right leg }\end{array}$ & NA & None & $\begin{array}{l}\text { TMP/ } \\
\text { SXM (3 } \\
\text { mo) }\end{array}$ & $\begin{array}{l}\text { Susceptible to } \\
\text { AMK and EM; } \\
\text { resistant to CN } \\
\text { and TOB }\end{array}$ & Cured \\
\hline $2013^{9}$ & $54 / M$ & $\begin{array}{l}\text { Gardening as } \\
\text { a hobby }\end{array}$ & $\begin{array}{l}\text { Fever }\left(39^{\circ} \mathrm{C}\right) \text {; } \\
\text { pain, swelling } \\
\text { and erythema of } \\
\text { left thigh }\end{array}$ & $\begin{array}{l}\text { Leprosy; } \\
\text { Diabetes } \\
\text { mellitus }\end{array}$ & Prednisone, thalidomide & $\begin{array}{l}\text { TMPI } \\
\text { SXM and } \\
\text { IPM (I } \\
\text { mo) }\end{array}$ & None & Cured \\
\hline $2014^{10}$ & $45 / F$ & NA & $\begin{array}{l}\text { Pain, swelling } \\
\text { and erythema of } \\
\text { right thigh }\end{array}$ & $\begin{array}{l}\text { Cogan's } \\
\text { syndrome }\end{array}$ & $\begin{array}{l}\text { Prednisolone, } \\
\text { ciclosporin }\end{array}$ & $\begin{array}{l}\text { AMC (6 } \\
\text { mo) }\end{array}$ & $\begin{array}{l}\text { Susceptible to } \\
\text { AMC and TMP/ } \\
\text { SXM, MI, DOX } \\
\text { and CLR }\end{array}$ & Cured \\
\hline
\end{tabular}

Abbreviations: AMK, amikacin; AMC, amoxicillin/clavulanic acid; CRO, ceftriaxone; IPM, imipenem; TMP/SXM, trimethoprim-sulfamethoxazole; MI, minocycline; CIP, ciprofloxacin; TOB, tobramycin; CLR, clarithromycin; LZD, linezolid; CN, gentamicin; EM, erythromycin; DOX, doxycycline; NA, not available. 
Table 2 Characteristics of the Patient from This Case Report

\begin{tabular}{|c|c|}
\hline Characteristic & Our Patient \\
\hline Age/gender & 55/Male \\
\hline Occupation & Electrician \\
\hline Main underlying conditions & $\begin{array}{l}\text { Nephrotic syndrome } \\
\text { Diabetes }\end{array}$ \\
\hline Maximum temperature & $37.8^{\circ} \mathrm{C}$ \\
\hline Clinical manifestations & Right thigh pain \\
\hline MRI results & Abscesses formation \\
\hline $\begin{array}{l}\text { Steroids and/or other } \\
\text { immunosuppressants }\end{array}$ & Steroid and cyclophosphamide \\
\hline Therapy & $\begin{array}{l}\text { Ceftriaxone/3 days } \\
\text { Piperacillin-tazobactam/4 days } \\
\text { TMP-SMX/3 days } \\
\text { Linezolid, TMP-SMX/19 days } \\
\text { TMP-SMX, amoxicillin- } \\
\text { clavulanate/6 months }\end{array}$ \\
\hline Other therapy & Abscess drainage/ $/ 0$ days \\
\hline Outcome/follow-up & Cured/6 months \\
\hline $\begin{array}{l}\text { Positive microbiology/incubation } \\
\text { time }\end{array}$ & 3 days \\
\hline Pathogen & N.farcinica \\
\hline Identification method & $\begin{array}{l}\text { MALDI-TOF-MS } \\
\text { Sequencing of the } 16 \mathrm{~s} \text { rRNA } \\
\text { genes } \\
\text { Modified Kinyoun acid-fast stain } \\
\text { Morphology }\end{array}$ \\
\hline
\end{tabular}

only cutaneous involvement and no systemic dissemination. Including our patient, the mean age of patients was 51 years (31-72 years), with a gender ratio of male/female of 1.34. All three male patients had experiences of working outdoors (as was our male patient). It is likely possible that high incidence of primary cutaneous nocardiosis is more related to occupation or experiences of working outdoors rather than gender factor.

A history of steroid and/or immunosuppressive therapy was found in all except two immunocompetent patients. Equally, for our patient, the nocardia infection is most likely to be associated with his diabetes and the use of steroid and cyclophosphamide. Therefore, the use of steroid and/or immunosuppressants is also a great risk factor in primary cutaneous nocardiosis. This is contrary to the previous conclusion that primary cutaneous nocardiosis is seen in immunocompetent hosts, ${ }^{3,5}$ which might be explained by the fact that immunocompetent hosts with nocardia infections resulting in soft-tissue inoculation by direct percutaneous trauma can be early and clearly detected. However, immunocompromised patients rapidly disseminate systemically to develop into other forms of nocardiosis, and it is difficult to distinguish where the primary lesion is from. Also, this primary cutaneous wound might be relatively minor because no trauma history was mentioned in six patients.

In these patients, there was no characteristic symptom besides only two revealed elevated body temperature. Abscesses or nodules of limbs with erythema, swelling and tenderness were the most common clinical presentation. We also find that, from symptom onset to admission, two immunocompetent patients experienced, respectively, two months and five months. The remaining immunosuppressed patients experienced periods ranging from seven days to three weeks. In contrast, the immunosuppressed patients' onset is more acute. For such patients, nocardiosis needs to be diagnosed and treated promptly.

Nocardia of diagnosis is mainly based on microbial cultures. Due to the slow growth of Nocardia, direct microscopy could rapidly acquire useful information for clinical treatment. In our case, the gram stain of pus showed gram positive slender filamentous bacteria. Microbiologist suspected Nocardia based on the negative result of pus cultures after 16 hours. After 24 hours, there were pinhead-sized colonies on blood agar plate and colonies gradually grew after 48 hours. Small and hard white colonies on blood agar plate were visible after 72 hours (Figure 1D). These colonies were partially acid fast by modified Kinyoun acid-fast stain (Figure 1C), and were later identified as N.farcinica by matrix-assisted laser desorption/ionization time-of-flight mass spectrometry (MALDI-TOF-MS) and sequencing of the 16s rRNA genes. As a result of pus samples from deep abscesses, isolation of bacteria is not difficult and it took only three days from sending pus samples to receiving definite result. Therefore, prolonged culture time are required when clinicians or microbiological workers suspect nocardiosis and the possibility of being overlooked in the presence of fastgrowing bacteria in microbial cultures needs to be considered.

Our patient had a recurring fever from day three after introduction of single oral TMP-SMX. By addition of intravenous linezolid, he showed a rapid relief. The choice of antibiotics and treatment regimen is not only 
determined by infection site, severity and individual condition but also Nocardia species. Compared with other species, $N$.farcinica has a distinctive antibiotic susceptibility pattern and shows resistance to ampicillin, thirdgeneration cephalosporins, clarithromycin and most aminoglycosides. It is mainly susceptible to amikacin, imipenem, ciprofloxacin and TMP-SMX. Although there are prevalently same results of resistance and susceptibility, each N.farcinica varies. The results of antimicrobial susceptibility testing are not identical in Table 1 . Unfortunately, our antimicrobial susceptibility testing could not be performed because of limitations of laboratory conditions. Therefore, for our patient, the empiric TMP-SMX did not work. If available, the treatment should be dependent on antimicrobial susceptibility testing. In addition, N.farcinica is particularly virulent and has a high risk of dissemination, especially central nervous system involvement. When it fails to be diagnosed, empirical antibiotics usually brings about high mortality. ${ }^{2}$ Therefore, Nocardia species identification and the results of antimicrobial susceptibility testing should be confirmed.

In conclusion, we describe a rare primary cutaneous nocardiosis by $N$.farcinica in a patient receiving long-term steroid and cyclophosphamide, which was treated with linezolid, TMP-SMX and ultrasound-guided drainage of abscesses. This disease has common features in that abscesses or nodules of limbs with erythema, swelling and tenderness, a chronic or subacute onset and its possibility of fever-free, common in outdoor workers, poor response to empiric antibiotics and hard to acquire valuable result of microbial cultures. Therefore, we suggest considering the possibility of cutaneous infection by N.farcinica when immunosuppressive or steroid-treated patients are suspected bacterial infections and present with the above conditions. Considerable importance should be attached to early diagnosis and appropriate treatment for fear of disseminated infections by delayed diagnosis.

\section{Abbreviations}

N.farcinica, nocardia farcinica; TMP-SMX, trimethoprimsulfamethoxazole; MRI, magnetic resonance imaging; MALDI-TOF-MS, matrix-assisted laser desorption/ionization time-of flight mass spectrometry; PCR, polymerasechain reaction; AMK, amikacin; AMC, amoxicillin/clavulanic acid; CRO, ceftriaxone; IPM, imipenem; MI, minocycline; CIP, ciprofloxacin; TOB, tobramycin; CLR, clarithromycin; LZD, linezolid; CN, gentamicin; EM, erythromycin; DOX, doxycycline; NA, not available.

\section{Consent Statement}

Written informed consent was provided by the patient to allow the case details and any accompanying images to be published.

No specific ethics committee approval was required for this study.

\section{Funding}

There is no funding to report.

\section{Disclosure}

The authors report no conflicts of interest in this work.

\section{References}

1. Ishiguro T, Yoshioka H, Kawai S, et al. A case of empyema and septic arthritis due to Nocardia farcinica. Clin Case Rep. 2017;5:1976-1979. doi:10.1002/ccr3.1228

2. Torres $\mathrm{OH}$, Domingo $\mathrm{P}$, Pericas R, et al. Infection caused by Nocardia farcinica: case report and review. Eur J Clin Microbiol Infect Dis. 2000;19:205-212. doi:10.1007/s100960050460

3. Brown-Elliott BA, Brown JM, Conville PS, et al. Clinical and laboratory features of the Nocardia spp. based on current molecular taxonomy. Clin Microbiol Rev. 2006;19:259-282. doi:10.1128/ CMR.19.2.259-282.2006

4. Angeles RM, Lasala RP, Fanning CV. Disseminated subcutaneous nocardiosis caused by Nocardia farcinica diagnosed by FNA biopsy and $16 \mathrm{~S}$ ribosomal gene sequencing. Diagn Cytopathol. 2008;36:266-269. doi:10.1002/dc.20804

5. Budzik JM, Hosseini M, Mackinnon AC, et al. Disseminated Nocardia farcinica: literature review and fatal outcome in an immunocompetent patient. Surg Infect. 2012;13:163-170. doi:10.1089/ sur.2011.012

6. Malani AK, Gupta C, Weigand RT, et al. Thigh abscess due to Nocardia farcinica. J Natl Med Assoc. 2006;98:977-979.

7. Bosamiya SS, Vaishnani JB, Momin AM. Sporotrichoid nocardiosis with cutaneous dissemination. Indian J Dermatol Venereol Leprol. 2011;77:535. doi:10.4103/0378-6323.82409

8. Jiménez GD, Albarrán PC, Galán SF, et al. Primary cutaneous nocardiosis caused by Nocardia farcinica. Rev Clin Esp. 2012;212:e49e51. doi:10.1016/j.rce.2012.02.015

9. De Nardo P, Giancola ML, Noto S, et al. Left thigh phlegmon caused by Nocardia farcinica identified by $16 \mathrm{~S}$ rRNA sequencing in a patient with leprosy: a case report. BMC Infect Dis. 2013;13:162. doi:10.1186/1471-2334-13-162

10. Merinopoulos D, Khan H, Ginwalla S, et al. Nocardia farcinica complicating Cogan's syndrome. Oxford Med Case Rep. 2014;2014:36-38. doi:10.1093/omcr/omu016 


\section{Publish your work in this journal}

Infection and Drug Resistance is an international, peer-reviewed openaccess journal that focuses on the optimal treatment of infection (bacterial, fungal and viral) and the development and institution of preventive strategies to minimize the development and spread of resistance. The journal is specifically concerned with the epidemiology of antibiotic resistance and the mechanisms of resistance development and diffusion in both hospitals and the community. The manuscript management system is completely online and includes a very quick and fair peerreview system, which is all easy to use. Visit http://www.dovepress.com/ testimonials.php to read real quotes from published authors. 